Article

\title{
Students' Views on Public Transport: Satisfaction and Emission
}

\author{
Dragan Stojic, Zoran Ciric*(D, Otilija Sedlak and Aleksandra Marcikic Horvat
}

Faculty of Economics Subotica, University of Novi Sad, 21000 Novi Sad, Serbia; stojicd@ef.uns.ac.rs (D.S.); otilijas@ef.uns.ac.rs (O.S.); amarcikic@ef.uns.ac.rs (A.M.H.)

* Correspondence: zoran.ciric@ef.uns.ac.rs; Tel.: +38-163-553-740

Received: 13 August 2020; Accepted: 6 October 2020; Published: 14 October 2020

\begin{abstract}
Overall satisfaction is an emotional response to a perceived discrepancy between expectations and perceptions. Overall satisfaction is more of a holistic affective construct after a service delivery experience, while transaction-specific satisfaction refers to attribute-based cognitive evaluation of service encounters. The authors investigated which particular attributes of public transport service drive satisfaction of customers, contributing to public transport becoming more sustainable. The questionnaire used in this research was constructed based on Benchmarking in European Service of Public Transport (BEST). The respondents belonged to the group of younger users of public transport services. Correlation analysis, factor analysis, and regression analysis were used in data processing and interpretation. Results obtained from the research show that young people emphasize the importance of on-line information, comfort, and prices of the public transportation. This paper not only provides insight into expectations of public transport users, but also investigated the potential decrease in $\mathrm{CO}_{2}$ and PM emissions when private vehicles are substituted with the public transport.
\end{abstract}

Keywords: public transport services quality; customer satisfaction; developing of attractive; sustainable and marketable public transport

\section{Introduction and Objectives}

The aim of this paper is to obtain a better understanding of overall customer satisfaction in public bus transport (PT) in the medium size city of Subotica, Serbia. The assessment as well as the improvement of public transport service quality are gaining importance with the increasing number of car owners. Furthermore, it is important to investigate which of the service quality attributes influence customer satisfaction the most. Another aim is to gain insight into the public transport's service quality structure in order to suggest specific quality improvements for a sustainable future. Finally, the authors investigate the potential decrease in carbon emission when private cars are substituted with PT in central city areas. The sustainability of future transport in general should indeed rely on public transportation as one of the key components. Nonetheless, to increase the number of passengers, "public transport must have high service quality to satisfy and fulfill more wide range of different customer's needs" [1].

A study by Replogle and Fulton [2] estimated that the increased use of public bus transport, bicycle transportation, and walking for commuters within city limits could have a conjoint effect in reducing emissions by a staggering $40 \%$ by the year 2050 . We believe that it is of utmost importance to learn the habits and views of the youngest users on public transport services in order to generate the set of actions towards overall improvements.

The attractiveness of PT in transportation studies is primarily considered by measuring technical aspects of the public transport services (for a comprehensive insight see, e.g., Currie and Wallis [3]), neglecting the customers' viewpoints. On the other hand, in economics and marketing, the management 
of consumer services is a topic that is studied extensively. Some research, including [4], use a regression model for assessing the effectiveness of public bus transport. This paper will focus on consumers' perception of technical quality of transportation service. We need to keep in mind that an "impartial" measure of technical quality focuses on PT needs itself, rather than the needs of passengers within the PT service [5].

This paper consists of four sections. After the introduction, where the main research question and objective are determined, the second section reviews the literature concerning satisfaction in public transport services. The third section presents the research methodology, and then the main results. The final section presents the main conclusions with special attention paid to the contribution of this research to the literature and future trends.

\section{Literature Review}

We commence the literature review with pointing out the well-known findings of the general consumer analysis, followed by more detailed insight into specific analyses concerning satisfaction in PT services. The approach of psychology and consumer behavior analysis is based on the assumption that satisfaction is a mental condition of the customer, and for this reason it should be linked with some comparison standards [6]. According to Zeithaml et al. [7], a customer perceives and assesses the notion of value "depending on sacrifice and the customer's frame of reference".

The most important measurement approaches, as stated in Grigoroudis and Siskos [8], may be categorized into: statistical and data analysis techniques, quality approach, consumer behavioral analysis, and other methodological approaches, including Kano's model, data envelopment analysis, multidimensional scaling, etc.

The problem with traffic congestion is particularly expressed in urban areas, where possibilities for physical increment of capacity are limited or impossible. Of particular significance for approaching to solve this problem are the usage of PT and the implementation of various advanced control measures that can improve the quality of overall public transport system. Public Transport Management Systems (PTMS) are systems that use information and communication technologies in order to increase efficiency and safety of PT systems and to provide the PT users with greater access to information on system operations [9].

The paper of Yanchun Yi and other authors [10] found the connection between urbanization and China's carbon emissions. When focusing on the relationship between satisfaction and behavior, various studies (e.g., [11-15]) imply that behavior is determined by satisfaction, while there are studies (e.g., [16-19]) stating that satisfaction does not exhaust all the determinants, even further that the satisfaction is neither necessary nor sufficient explanation for behavior. For example, Cronin [20] claims that "not all satisfied customers return for a repurchase and not all dissatisfied customers disappear".

The quality of PT performance can be appraised on different levels and from different perspectives. Such evaluations range from individual lines and corridors, via the behavior of multi-line systems up to the transnational comparison of cities and their PT characteristics [21]. The efficiency of transport operators as well as the authorities could be increased if they were more sensible to the needs and requirements of the existing customers. Local authorities and municipality administrations shape, in accordance with their interests, the transportation tariff and provisions for certain social categories and thus the necessary subsidies to cover the operating costs and the necessary grants to cover the investment costs (vehicle and infrastructure) [22].

The overall increased demand for travel has triggered the increase in usage of private cars, leading to rapid motorization worldwide. In some countries (such as Austria and Hungary), the local government has initiated the public transportation development in order to appeal citizens to take public transport instead using private cars [23]. "Most people are now highly dependent on private motorized travel" [24]. Increased private motorization has resulted in an increased traffic congestion, leading to longer travel times. 
The problem of customer needs in public transport has been extensively conducted by the UK Department for Transport [25]. High frequency of service, services that are reliable, and fares that offer value for money were revealed as the most important needs of UK public transport users. The bus also has to have a broad range of destinations to fulfill the travel demands of customers. Cordera's paper [26] enquired as to which factors explain the spatial differences in satisfaction with public transport services in the town. Furthermore, the report revealed "the importance of understandable time table information in bus stop and in local newspaper in order to make them aware of the existence of the service." (http://www.gov.uk/government/organisations/department-for-transport) Customers have also stressed the importance of user-friendly ticket-buying solutions so they would opt for public transport. Another UK study [27] investigated affective experiences of daily commute of Surrey University's employees. The results revealed that traffic volume induces stress to commuters both by car as well as by public transport. Public transport was perceived as unpleasant and public transport users expressed a more negative attitude toward their daily commute than users of other transport modes.

Fellesson and Friman [28] carried out an extensive study on customers' satisfaction in the domain of public transportation. The study covered eight European cities. The research results have recognized four general categories of satisfaction: systemic (concerning satisfaction with traffic supply, reliability and information); design (a category that includes comfort and overall travel experience); staff (deals with skill, knowledge, and attitude toward customers); and safety (on the bus, at the bus stop, as well as safety from traffic accidents). Finally, Eboli and Mazzulla [29] launched the survey on attributes which determine customer satisfaction. The respondents were asked to rate the bus service in the Italian city of Cosenza. The results show that the latent variable important for global customer satisfaction is service planning, which is mostly reflected in reliability, frequency, information, promotion, personnel, and complaints.

Rana Imam, in her study [30], measured the public transport satisfaction in the city of Amman, the capital of Jordan. A user survey was developed to explore the satisfaction of bus users, minibus users, and jitney users, and the results showed that the bus users were found to be the most satisfied. The survey consisted of two parts; the first part contained general questions about gender, age, occupation, and the most regularly used transit mode. The second part was the major part of the questionnaire, which consisted of 18 travel attributes. The analysis of the ANOVA results revealed that the users of the three public transportation modes disagreed regarding the following features: AC Availability, Availability of the Transit Service, Ease of Entering/Exiting the vehicle, Ease of payment, and Staff Behavior.

The studies of de Ona and Ona [31] and other authors [32,33] looked at the quality of public transport service based on customer satisfaction surveys. These authors summarized the evolution of research and current thinking as it relates to the different methodological approaches for service quality evaluation in the public transport sector over the years.

Group of authors in Slovakia [34] investigated the dependence between the socio-demographic characteristics of the respondents and the intensity of the use of public transport in order to determine the key determinants of the public transport user's satisfaction. It is interesting to mention that age was one of the significant variables having an impact on intensity of use of the suburban bus transport. Therefore, it would be an interesting to link this topic with the generational theory in the future research. The recently added papers Kral et al. [34] and Imam [30] analyzed public transport satisfaction using standard statistical methodology similar to our research. It is also interesting to point out that majority of respondents in the survey of public transport satisfaction in Jordan Imam were students, therefore those results are valuable for comparison. Authors de Ona and Ona [31] presented valuable overview of papers and methodology in this field. They also mentioned that factor analysis is usually used as a preliminary step for other methods, such as multiple linear regression analysis or structural equations models. Therefore, our future research will be directed to the development of structural equations models. 
May [35] identified which innovations are unavoidable in public transport policy if it is necessary to save sustainability in this area, providing the users with satisfaction for sustainable public transport model development [36]. Collecting vehicle flow data is a prerequisite for assessing the status of the existing system, as well as for deciding on measures and solutions that should be taken to improve the condition of the system. Miletić et al. [37] analyzed the aspects which can influence the choice between public or private car transportation. In that analysis, they measured the basic demographic and socioeconomic characteristics of the public transport in Croatia. They used binary logistic regression analysis to analyze preferences by the age of travelers, size of the settlement, customer satisfaction, accessibility of the target point by public transport, and others.

Finally, Stuart et al. (2000) [38] used the Structural Equation Model (SEM) to model customer satisfaction. The model is proposed for explaining a causal link between a sequence of variables. This method can be used to examine a graph of interrelated variables. According to authors, speed of service and security act as intermediaries between the set of explanatory variables and the overall satisfaction. We pursue the multiple regression model in our paper as an attempt to explain relationships between variables.

\section{Research Methodology}

Previously reviewed research papers focused mostly on wide range of customer age in order to perceive a full insight into the customer satisfaction of public transport. The scope of this paper, however, investigated overall customer satisfaction among younger people, i.e., Generation Z. We used the overall customer satisfaction as a dependent variable in this research. We observed the qualities of PT service in the city of Subotica, Serbia. The city-specific statistics concerning passenger transportation are briefly presented in the following paragraphs.

Subotica is the second largest city in the Autonomous Province of Vojvodina, located in the far north of the country, along the border with the Republic of Hungary. Subotica is located on the edge of Central Europe and the Balkans, on the crossroad that leads to all four corners of the world, next to the international road E75. The city has about 100,000 inhabitants, it is very recognizable for its multiethnicity, multiculturalism, and great tolerance of its citizens. Subotica is also an academic city, with three faculties and two colleges. About 1000 students live in the city during the school year. These are students of social humanities and technical sciences.

The average age of private cars in the city of Subotica is just under 15 years (14.8), based on the anonymous survey taken during the last three months of 2018 at the local Registration office. This age is slightly below the national average of 16 years, but well above the EU average of 9.7 years. The number of private cars is 280 per 1000 citizens, which is above the national average of 220, but below the EU average of one car per two citizens.

Figures and maps were collected through annual reports of Subotica's bus company, as well from Belgrade public transport company, for comparison.

As far as public transportation is concerned, the city of Subotica is covered by nine bus lines, presented in Figure 1a. The bus network is the only means of PT, and "Subotica trans" is the company that runs this business in the city. The line density is one line per 11,000 inhabitants. The fleet consists of 88 buses with an average age of 11.5 years, all running on euro diesel. For the comparison, the average age of urban buses in the EU is 7.6 years, and the average age of trolleybuses is 11 years. When compared to Serbia's capital city in terms of public line density, Belgrade is far better off, with 4000 citizens per line in Belgrade proper, i.e., 2700 citizens per line in the metropolitan area. Subotica is also in a weaker position compared to Serbia's second biggest city, Novi Sad, where the number of citizens per one bus line is 6500 .

The core of the city is not completely car-free, and the transversal road splitting the city center into two halves is especially busy and open to all types of vehicles. The two major crossroads are located on the eastern and western edges of the city center, as denoted in Figure 1a,b with stars. 


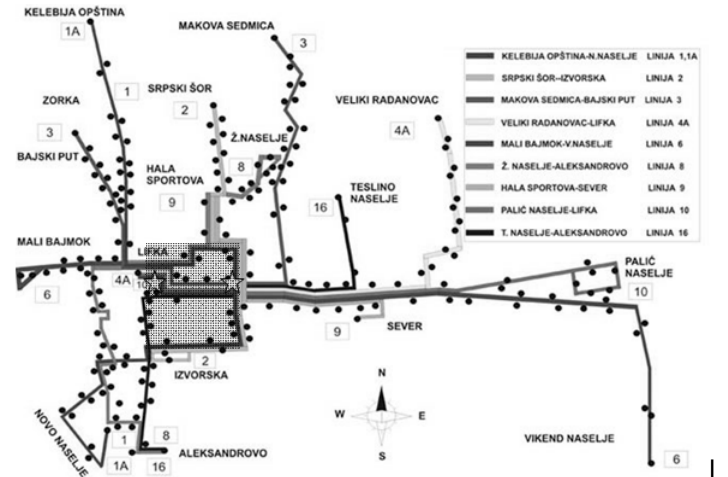

(a)

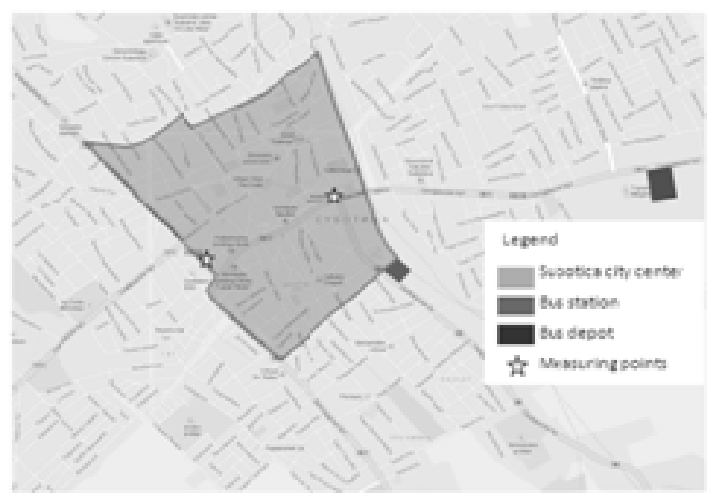

(b)

Figure 1. Routes of the city lines (a) and the position of city center (b).

As indicated in Figure 1a, there are nine regular public bus lines covering major communication directions in the city. In the figure, the locations of bus stops are indicated with black dots. Numbers in squares show departure points; departure times are published by the operator through official timetables.

In order to collect data, the authors used a questionnaire as the most appropriate tool when measuring customers' satisfaction. The questionnaire was constructed so as to provide the main social and economic dimensions of public transportation sustainability. PT users were not asked about their views on the ecological dimension of transportation, rather these data were collected in situ, by direct traffic counting. These data were paired with the data continuously collected by the sampler on concentration of carbon oxide (CO), nitrogen oxide $\left(\mathrm{NO}_{2}\right)$, and fine particulate matter (PM2.5). Two samplers were positioned near the city center at the two crossroads mentioned, denoted by stars in the maps.

The total number of questionnaires distributed was 210, of which 201 were answered and utilizable for further analysis. Respondents were aged between 18 and 26 years. These respondents had been using PT facilities at least once a week. Respondents usually used different numbers of bus lines during a week to get to the desired destinations: 97 respondents only used one line, 68 used two lines, 22 used three lines, and 14 respondents used more than three lines.

The questionnaire was assembled through the expansion of a system of questions taken from Benchmarking in European Service of PT (BEST) [39]. BEST is a European initiative (a non-profit project) started in 1999, which aims at updating information on customer satisfaction of the PT system and making plans to enhance the use of PT.

The questionnaire included 13 different statements about the quality of PT, 1 question about general satisfaction with the PT in the city, and 3 statements about alternative mobility possibilities and their impact on the environment. Respondents could give grades on a five-point Likert-type scale ranging from 1 to 5; grade 1 means the lowest level of agreement (lowest quality of the service) and 5 is related to the highest level of agreement (best quality of service). The specific attributes included: PT departure frequency $\left(Q_{1}\right)$, travel time $\left(Q_{2}\right)$, punctuality $\left(Q_{3}\right)$, price $\left(Q_{4}\right)$, on-line information $\left(Q_{5}\right)$, cleanliness on board $\left(Q_{6}\right)$, onboard staff behavior $\left(Q_{7}\right)$, bus comfort $\left(Q_{8}\right)$, onboard security $\left(Q_{9}\right)$, seat availability $\left(\mathrm{Q}_{10}\right)$, bus stop security $\left(\mathrm{Q}_{11}\right)$, bus stop condition $\left(\mathrm{Q}_{12}\right)$, and information at bus stops $\left(\mathrm{Q}_{13}\right)$. Additional questions were related to the next issues: introduction of hybrid city buses contributes to air pollution reduction $\left(\mathrm{Q}_{14}\right)$, popularization of bicycles causes their use to be more frequent, and that contributes to air pollution reduction $\left(\mathrm{Q}_{15}\right)$, and willingness to regularly use bicycles in the case that an appropriate bicycle road network covers the whole city $\left(\mathrm{Q}_{16}\right)$. The 17 th question $\left(\mathrm{Q}_{17}\right)$ aimed to get respondents' views on the overall quality of PT services. 


\section{Results and Discussions}

In Table 1 the averages of scores given to particular questions are presented, along with standard deviation values. The items are sorted from the highest to the lowest score. The highest score was awarded to on-line information about PT, and a relatively high position was given to prices and situation at bus stops. On the other hand, the situation during travel, i.e., in the very buses, was graded lower. The estimated ranges of scores (standard deviation) was almost the same for particular questions (1.04-1.28). The difference between the mean of average scores and the mean score for overall satisfaction the difference was small and not significant $(p=0.13)$.

Table 1. Average scores for the items in the questionnaire.

\begin{tabular}{cccc}
\hline No & Satisfaction with the Quality of: & Average Score & Standard Deviation \\
\hline 1 & On-line information & 4.17 & 1.04 \\
2 & Price & 3.46 & 1.30 \\
3 & Bus stop security & 3.45 & 1.17 \\
4 & Public bus transport departure frequency & 3.39 & 1.20 \\
5 & Information at bus stops & 3.36 & 1.28 \\
6 & Bus stop condition & 3.19 & 1.13 \\
7 & Punctuality & 2.90 & 1.14 \\
8 & Onboard staff behavior & 2.88 & 1.20 \\
9 & Travel time & 2.85 & 1.07 \\
10 & Onboard security & 2.74 & 1.06 \\
11 & Bus comfort & 2.20 & 1.02 \\
12 & Seat availability & 2.08 & 1.03 \\
13 & Cleanliness on board & 2.07 & 1.15 \\
$\mathrm{~m}$ & Mean of average scores & 2.98 & 0.61 \\
17 & Mean overall satisfaction & 3.08 & 0.72 \\
\hline
\end{tabular}

The data series of average values of answers from the 201 respondents is normally distributed $(\mathrm{JB}=0.97, p=0.62)$; the distribution is slightly negatively skewed $(\mathrm{S}=-0.17)$, meaning that it has a longer left tail, but this does not differ significantly from normal distribution $(p=0.16)$. Figure 2 illustrates the empirical distribution of average scores and the normal curve. As corresponding to the normal distribution, it appears that the majority of respondents gave scores that were close to the overall mean of all respondents (2.99), and few gave scores that were apart from that, either towards higher (score 5) or towards lower values (score 1). No respondent gave uniform answers (all variation coefficients are over 15\%), it might be concluded that the questionnaire was filled with great responsibility and a serious approach.

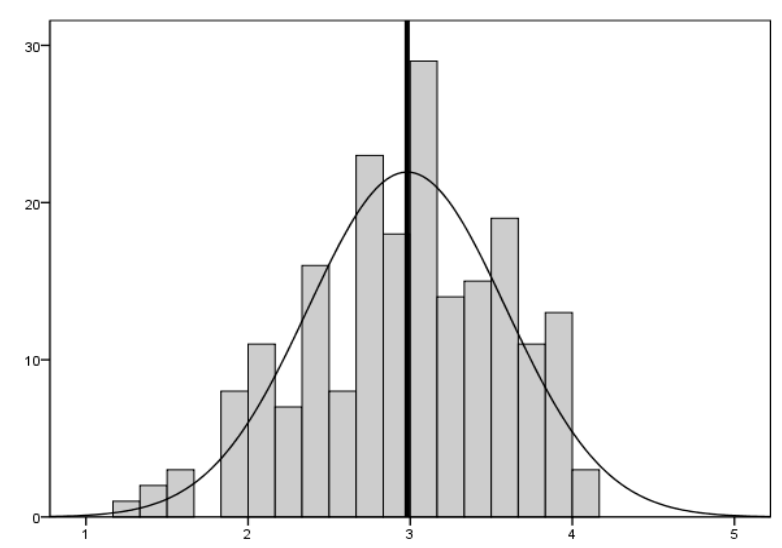

Figure 2. Distribution of average scores and the normal curve. Horizontal axis: average scores, vertical axis: number of respondents; Vertical bold line: mean of average scores (2.99). 
Estimation of stability between answers about the overall satisfaction and average value of answers to the first 13 questions related to the quality of urban transport was performed using the Pearson's correlation coefficient (although this coefficient measures linear relationships, it can be used to compare a continuous variable (average scores) and a discrete variable of Likert-type (overall scores) if the scale has five or more items; the downward bias because of discreetness is minor). The coefficient amounted to 0.889 ; this means there is a strong relationship between average scores and overall scores; the calculated coefficient significantly differs from $0(p=0.000)$. Cronbach's alpha was used for testing the reliability of responses given for different items in the questionnaire. The calculated alpha was 0.791, which is over the recommended threshold value of 0.7 ; this points towards the satisfactory height of internal consistency of measurement items used in the questionnaire about the level of satisfaction with the quality of urban transport services.

The next step in the questionnaire analysis took account of correlations in order to observe the level of linear connections between any pair of 13 questions. In the next table (Table 2), correlation coefficients are shown, with level of significance below. The coefficients (except one significant) are positive, which means there was no contradiction in answers from each respondent. The only significant negative connection is between Q5 (on-line information) and Q10 (seat availability); these items are logically apart and the only possible reasonable explanation is that on-line information does not offer data about free seats on any city bus line. Also, every particular score is significantly correlated with the statement about the general satisfaction with urban transport quality (the last line of the table). The majority of coefficients between items are significant; items Q2 (travel time), Q3 (punctuality), Q4 (price), and Q5 (on-line information) only show insignificant correlations with several other items; we intend to clarify the meaning of these significant and insignificant correlations by the means of factor analysis, and find out which of the items form interconnected clusters.

In the Table 3, results of the linear regression of connections of overall satisfaction as the dependent variable and the scores for the first 13 items as explanatory variables are given. The applied estimation method was ordinary least squares, all 201 observations were included. The significance of the constant was not of interest; out of 13 variables only the score for question Q12 (bus stop condition) is insignificant $(p=0.187)$, other variables either significantly $(p<0.05)$ or highly significantly $(p<0.01)$ differ from 0. The fraction of variations of the dependent variable explained by independent variables is given by $\mathrm{R}$-squared $=0.798$, its significance was tested using $\mathrm{F}=56.79(p=0.0000)$. Test of multicollinearity using tolerance showed that there is not any so strong interdependence between explanatory variables, that would bias the regression results (tolerance $>0.1, \forall i$ ). All the estimated coefficients are positive. Every variable could take value in the same interval (1-5), the magnitude of the estimated coefficients could point to the importance of particular variables in forming of the value of the dependent variable. In this sense, first place belongs to bus stop security (Q1), punctuality (Q3), cleanliness on board (Q6), and price (Q4); it may be concluded that these items contribute the most to overall satisfaction with urban transport services. At the end of the row stand onboard security (Q9), travel time (Q2), on-line information (Q5), and bus stop condition (Q12).

Factor analysis was used to form groups of interconnected variables, to enable further reliability analysis of the questionnaire and to imply regression analysis as means of calculating the impact of each factor. The outcomes of factor analysis are regarded as fairly independent groups of factors, and it is hence possible to suggest actions to improve customers' satisfaction by groups of variables instead of individual determinants of the general satisfaction. 
Table 2. Correlation matrix of explanatory variables.

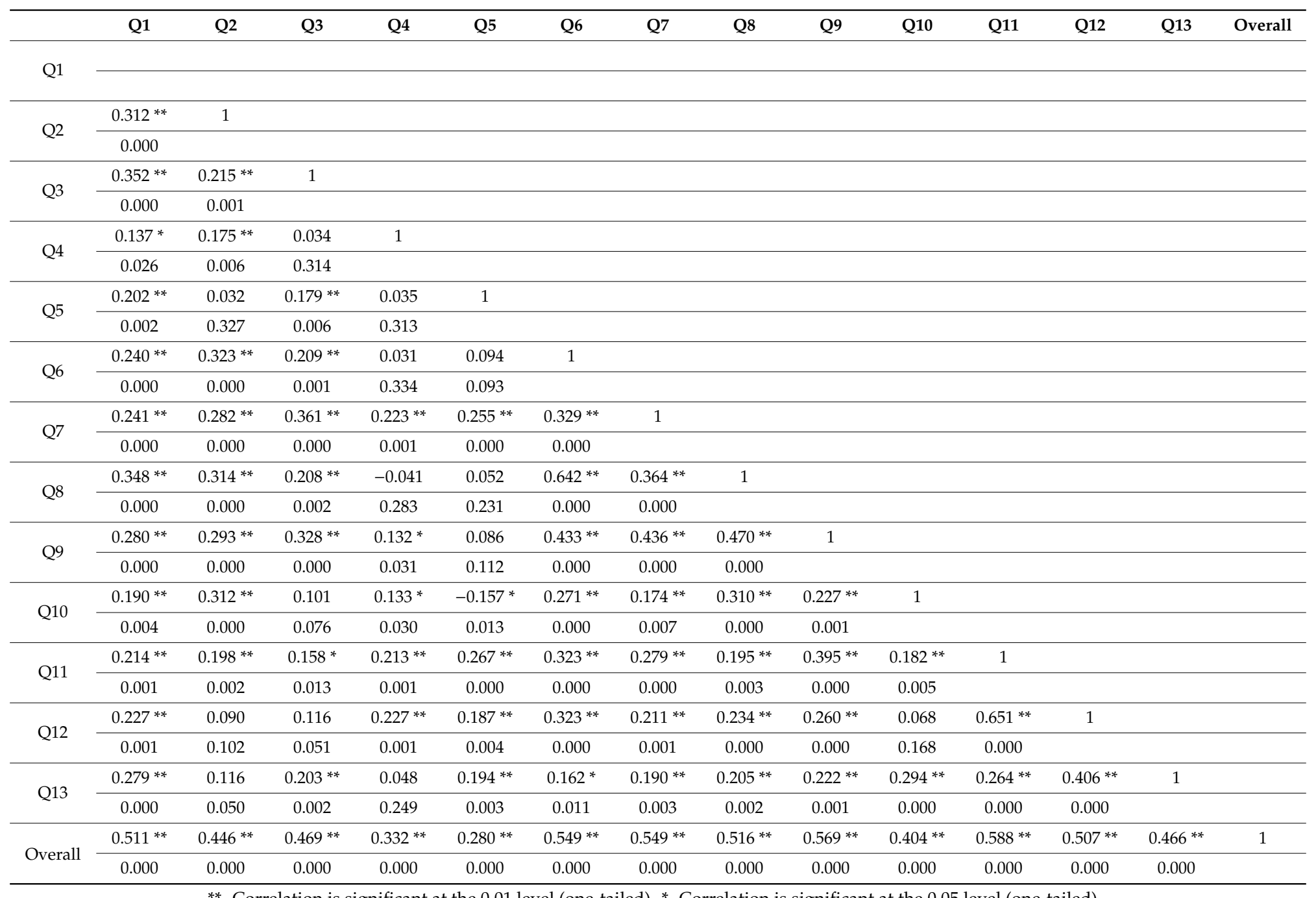

**. Correlation is significant at the 0.01 level (one-tailed). *. Correlation is significant at the 0.05 level (one-tailed). 
Table 3. Linear regression results—explained variable: overall satisfaction.

\begin{tabular}{cccccccc}
\hline \multirow{2}{*}{ Explanatory Variables } & Symbol & $\begin{array}{c}\text { Coefficient } \\
\text { Rank }\end{array}$ & $\begin{array}{c}\text { Estimated } \\
\text { Coefficient }\end{array}$ & $\begin{array}{c}\text { Standard } \\
\text { Error }\end{array}$ & $\begin{array}{c}\text { Test } \\
\text { Statistics }\end{array}$ & Significance & $\begin{array}{c}\text { Collinearity } \\
\text { Statistics-Tolerance }\end{array}$ \\
Constant & $\mathrm{C}$ & & 0.007 & 0.142 & 0.048 & 0.962 & \\
\hline $\begin{array}{c}\text { Public bus transport } \\
\text { departure frequency }\end{array}$ & $\mathrm{Q} 1$ & 7 & 0.079 & 0.023 & 3.399 & 0.001 & 0.712 \\
\hline Travel time & $\mathrm{Q} 2$ & 11 & 0.062 & 0.026 & 2.430 & 0.016 & 0.752 \\
\hline Punctuality & $\mathrm{Q} 3$ & 2 & 0.109 & 0.024 & 4.553 & 0.000 & 0.756 \\
\hline Price & $\mathrm{Q} 4$ & 4 & 0.091 & 0.020 & 4.546 & 0.000 & 0.829 \\
\hline On-line information & $\mathrm{Q} 5$ & 12 & 0.051 & 0.026 & 1.997 & 0.047 & 0.775 \\
\hline Cleanliness on board & $\mathrm{Q} 6$ & 3 & 0.092 & 0.029 & 3.193 & 0.002 & 0.515 \\
\hline Onboard staff behavior & $\mathrm{Q} 7$ & 8 & 0.075 & 0.024 & 3.060 & 0.003 & 0.652 \\
\hline Bus comfort & $\mathrm{Q} 8$ & 9 & 0.070 & 0.034 & 2.069 & 0.040 & 0.467 \\
\hline Onboard security & $\mathrm{Q} 9$ & 10 & 0.063 & 0.029 & 2.165 & 0.032 & 0.594 \\
\hline Seat availability & $\mathrm{Q} 10$ & 6 & 0.084 & 0.028 & 3.056 & 0.003 & 0.699 \\
\hline Bus stop security & $\mathrm{Q} 11$ & 1 & 0.133 & 0.030 & 4.496 & 0.000 & 0.466 \\
\hline Bus stop condition & $\mathrm{Q} 12$ & 13 & 0.041 & 0.031 & 1.324 & 0.187 & 0.456 \\
\hline Information at bus & $\mathrm{Q} 13$ & 5 & 0.087 & 0.022 & 3.896 & 0.000 & 0.690 \\
\hline stops & & & & & & & \\
\hline
\end{tabular}

In this procedure the Kaiser's criterion for selecting factors with VARIMAX rotation was applied. The Kaiser criterion keeps those factors whose eigenvalues are greater than 1 (the most commonly used criterion, proposed by Kaiser [40]). Kaiser-Meyer-Olkin Measure of Sampling Adequacy shows that data obtained from the questionnaire are suited for factor analysis; in this analysis $\mathrm{KMO}=0.734$, which is greater than the threshold value (0.6), so the data are exploitable for modeling. Bartlett's test for sphericity was used to find redundancy between variables that can be summarized with some factors. This test gave approximate Chi-squared value $\chi^{2}=684.10$ and $p=0.000$; since $p<0.05$, the factor analysis was valid for the data from this questionnaire (since Q5 and Q12 belong to the same factor and they are negatively correlated, coding of Q5 was changed, so that all results in the rotated component matrix become positive using Q5(c)).

The results of factor analysis are given in Table 4 .

After application of the principal component analysis for extraction and varimax rotation with Kaiser normalization, five factors were extracted, which explained $67.27 \%$ of the total variance.

- The first factor (F1) summarized the quality and the functionality while using the transportation means (city buses):

$\begin{array}{ll}\bigcirc & \text { Cleanliness on board (Q6); } \\ & \text { Bus comfort (Q8); } \\ \bigcirc & \text { Onboard security (Q9); } \\ & \text { Onboard staff behavior (Q7); } \\ & \text { Travel time (Q2). }\end{array}$

- The second factor (F2) encompassed the features of bus stops:

Bus stop condition (Q12);

- Bus stop security (Q11);

$\bigcirc \quad$ Information at bus stops (Q13).

- The third factor (F3) was related to satisfaction related to the time table:

$\bigcirc \quad$ Punctuality (Q3);

$\bigcirc \quad$ Public bus transport departure frequency (Q1). 
- The fourth factor (F4) has the pair of seat availability and on-line information:

- Seat availability (Q10);

O On-line information (Q5).

- The fifth factor (F5) consisted of a single item:

\section{$\bigcirc \quad$ Price $(\mathrm{Q} 4)$}

Cronbach's alpha and composite reliability measure were used to check the reliability of responses given for items belonging to the first and the second factor (restrictive assumptions of Cronbach's alpha implementation meant that the test could not be performed for two items). Results point to the satisfactory reliability of extracted groups of items for the first factor $\left(\alpha_{1}=0.758\right)$. For the second factor, alpha was less than the threshold value $\left(\alpha_{2}=0.694\right)$, but since Cronbach's alpha tends to bias the results towards lower values when there are few items in a group, the composite reliability measure (CRM) was also calculated for these two factors, which gave satisfactory results (CRM1 $=0.775$, CRM2 $=0.786$ ). As for the third and the fourth factors, the factor analysis could be appropriate, since the related correlations $\mathrm{r}(\mathrm{Q} 3, \mathrm{Q} 1)$ and $\mathrm{r}(\mathrm{Q} 10, \mathrm{Q} 5)$ are significant (Table 4).

Table 4. Rotated component matrix grouping service quality factors.

\begin{tabular}{ccccccc}
\hline No & Symbol & F1 & F2 & F3 & F4 & F5 \\
\hline 1 & Q6 & 0.821 & & & & \\
\hline 2 & Q8 & 0.805 & & & & \\
\hline 3 & Q9 & 0.651 & & & & \\
\hline 4 & Q7 & 0.481 & & & & \\
\hline 5 & Q2 & 0.390 & & & \\
\hline 6 & Q12 & & 0.863 & & \\
\hline 7 & Q11 & & 0.759 & & & \\
\hline 8 & Q13 & & 0.589 & & & \\
\hline 9 & Q3 & & 0.739 & & \\
\hline 10 & Q1 & & & 0.663 & & \\
\hline 11 & Q10 & & & 0.796 & \\
\hline 12 & Q5 (c) & & & & 0.515 & \\
\hline 13 & Q4 & & & & 0.868 \\
\hline
\end{tabular}

(c): coding of the adjusted item.

All factors formed groups of logically interconnected items, therefore regression analysis of the dependence of overall satisfaction with factors could show which newly defined variables (given with factor scores) have significant influence on the dependent variable. The share of variations of the dependent variable explained by factors is $R^{2}=79.00 \%$, test statistic of significance is $F=147.08$, $p=0.000$. Estimation results are presented in the next table (Table 5).

Values of the estimated regression coefficients show that the quality and the functionality of the transportation (items comprising factor 1: cleanliness on board, bus comfort, onboard security, onboard staff behavior, and travel time) have stronger influence on overall customer satisfaction than items contained in other factors. The second value is also related to functional issues (F3: punctuality and PT departure frequency). Hence, in order to improve the overall satisfaction, it is advisable to focus on functional factors. Besides that, strong influence on overall satisfaction could be attached to bus stop quality as well (Factor 2). The social dimension of PT sustainability is embodied in three factors, through bus stop security, staff behavior, on-board security, bus comfort, and seat availability. Being segmented in this way only makes it more difficult for policy-makers to achieve a better overall 
social aspect for commuters. The economic dimension is spread through several factors, relating to the condition of buses, of bus stops, and prices.

Table 5. Linear regression results—explained variable: overall satisfaction.

\begin{tabular}{|c|c|c|c|c|c|c|c|}
\hline \multirow{2}{*}{$\begin{array}{l}\text { Explanatory } \\
\text { Variables }\end{array}$} & \multirow[t]{2}{*}{ Symbol } & \multirow{2}{*}{$\begin{array}{l}\text { Coefficient } \\
\text { Rank }\end{array}$} & $\begin{array}{l}\text { Estimated } \\
\text { Coefficient }\end{array}$ & $\begin{array}{l}\text { Standard } \\
\text { Error }\end{array}$ & $\begin{array}{c}\text { Test } \\
\text { Statistics }\end{array}$ & Significance & \multirow{2}{*}{$\begin{array}{c}\text { Collinearity } \\
\text { Statistics-Tolerance }\end{array}$} \\
\hline & & & B & $\mathbf{S}$ & $t$ & $p$ & \\
\hline Constant & $\mathrm{C}$ & & 3.085 & 0.024 & 131.076 & 0.000 & \\
\hline Factor scores 1 & $\mathrm{~F} 1$ & 1 & 0.355 & 0.024 & 15.043 & 0.000 & 1.000 \\
\hline Factor scores 2 & $\mathrm{~F} 2$ & 3 & 0.326 & 0.024 & 13.814 & 0.000 & 1.000 \\
\hline Factor scores 3 & F3 & 2 & 0.344 & 0.024 & 14.564 & 0.000 & 1.000 \\
\hline Factor scores 4 & $\mathrm{~F} 4$ & 5 & 0.148 & 0.024 & 6.280 & 0.000 & 1.000 \\
\hline Factor scores 5 & F5 & 4 & 0.193 & 0.024 & 8.167 & 0.000 & 1.000 \\
\hline
\end{tabular}

There is another interesting issue connected to these results, namely, it appears that the respondents have given greater importance to items which they are less satisfied with (not observing factor 4). So, the most important factor is F1, where the average score for the five included items was 2.55 , the next factor by importance is F3, with average score 3.15, the next is F2, with average score 3.33, and the fourth is F5, with an average of 3.46. It may be concluded that, despite other possible considerations about PT, actions should be taken towards those items where the customers are less satisfied; in this case this is directly connected to the quality of services customers experience during riding the city buses. If this is applicable to other problem-solving cases, there is an easy way to find out directions of improving actions quickly and easy on the basis of gathering public opinion.

After gaining information on the attitude of young people on the quality of PT in the town where they live, authors tried to reveal their attitude towards some environmental issues. Questions contained in the questionnaire connected to the ecological dimensions of the sustainable transport were relatively simple: introduction of hybrid city buses contributes to air pollution reduction (Q14) and popularization of bicycles causes their use to be more frequent, and that contributes to air pollution reduction (Q15). To help respondents answer these questions they were presented with excerpts from the results of recent investigation of the authors about connections of traffic and air pollution in Subotica.

In this investigation, the impact of all types of vehicles passing through the city center's main road was measured. During two consecutive days (26 and 27 March 2019), the direct traffic count took place at determined locations from 8 a.m. until 5 p.m. Vehicles were divided into five groups: motorcycles (M), private cars (P), public busses (A), light trucks (up to $3.5 \mathrm{t}$ ) (L), and heavy trucks and trucks with trailers (over $3.5 \mathrm{t}$ ) (T). The distance between the two crossroads (denoted by stars in Figure $1 \mathrm{a}, \mathrm{b}$ ) was $900 \mathrm{~m}$, and the fixed passive sampler was placed at the right crossroad. The sampler continuously collected data on concentration of carbon monoxide (CO), nitrogen oxides (NOx) and fine particulate matter (PM2.5). The number of vehicles passing through the crossroad on an hourly basis is given in the Table 6 :

Table 6. Data from traffic counting.

\begin{tabular}{cccccccccccc}
\hline Type & & $\mathbf{8} \mathbf{h}$ & $\mathbf{9} \mathbf{h}$ & $\mathbf{1 0} \mathbf{h}$ & $\mathbf{1 1} \mathbf{h}$ & $\mathbf{1 2} \mathbf{h}$ & $\mathbf{1 3} \mathbf{h}$ & $\mathbf{1 4} \mathbf{h}$ & $\mathbf{1 5} \mathbf{h}$ & $\mathbf{1 6} \mathbf{h}$ & $\mathbf{1 7} \mathbf{~}$ \\
\hline Private cars & $\mathrm{P}$ & 2344 & 2583 & 2537 & 2461 & 2553 & 2437 & 2344 & 2467 & 2334 & 2008 \\
Light trucks & $\mathrm{L}$ & 143 & 133 & 181 & 174 & 170 & 237 & 230 & 196 & 191 & 115 \\
Heavy trucks & $\mathrm{T}$ & 58 & 59 & 54 & 67 & 68 & 77 & 67 & 68 & 53 & 40 \\
Motorcycles & $\mathrm{M}$ & 64 & 70 & 54 & 76 & 80 & 60 & 37 & 51 & 43 & 17 \\
Public buses & $\mathrm{A}$ & 82 & 42 & 47 & 39 & 49 & 63 & 64 & 61 & 51 & 40 \\
\hline
\end{tabular}

The data on emissions from individual types of vehicles were taken from the study of Papic et al. [41].

Example 1: using data from Table 7 one can easily calculate the average emissions for private cars and public busses. The figures are as follows: 
Private cars running on petrol: CO between 3.5 and $24.5 \mathrm{~g}$, NO between 0.42 and $2.45 \mathrm{~g}$, and PM between 0.0021 and 0.00315 .

Figures for diesel cars are: CO between 0.12 and 0.66 , NO between 0.54 and $0.84 \mathrm{~g}$, and PM between 0.042 and 0.24 .

Figures for busses are: CO between 1.1 and $7.5 \mathrm{~g}$, NO between 2.75 and 15, and PM between 0.005 and $0.018 \mathrm{~g}$.

According to [42], the ratio of petrol cars to diesel cars in 2018 was roughly 3:8, so we can estimate the emissions of an 'average' private car as a weighted average with the weights 3 and 8 , respectively. Hence, the total of 2300 cars' emission is everything between:

\begin{tabular}{|l|l|l|}
\hline CO & 2396.182 & 16472.18 \\
\hline NO & 1166.727 & 2941.909 \\
\hline PM & 71.57182 & 403.4305 \\
\hline
\end{tabular}

A total of 2300 cars carry approximately 3000 persons, who would fit in roughly 90 public busses emitting the total of:

\begin{tabular}{|l|r|r|}
\hline CO & 99 & 675 \\
\hline NO & 247.5 & 1350 \\
\hline PM & 0.45 & 1.62 \\
\hline
\end{tabular}

This striking difference was obtained just for one kilometer of road through the city center.

The minimal and maximal emission levels of carbon monoxide, nitrogen oxides, and particulate matter (in grams per $1 \mathrm{~kg}$ of fuel consumed), as well as average fuel consumption per each type vehicles are given in Table 7 (relatively little exploration has been done about spatial components; for example, the wind speed was not used in the examination).

Table 7. Average consumption and emission statistics for five types of vehicles.

\begin{tabular}{|c|c|c|c|c|c|c|c|c|}
\hline \multirow{2}{*}{$\begin{array}{l}\text { Type of } \\
\text { Vehicle }\end{array}$} & \multirow{2}{*}{$\begin{array}{c}\text { Type } \\
\text { of Fuel }\end{array}$} & \multirow{2}{*}{$\begin{array}{l}\text { Fuel Cons. } \\
\text { g/km }\end{array}$} & \multicolumn{6}{|c|}{ Emission Levels (g/kg of Fuel) } \\
\hline & & & $\mathrm{CO} \min$ & CO max & NOxmin & NOx max & PM min & PM max \\
\hline \multirow{3}{*}{ Private cars } & Petrol & 70.0 & 50.0 & 350 & 6.0 & 35 & 0.03 & 0.045 \\
\hline & Diesel & 60.0 & 2.0 & 11 & 9.0 & 14 & 0.70 & 4.000 \\
\hline & LPG & 57.5 & 40.0 & 115 & 6.0 & 40 & 0.00 & 0.000 \\
\hline \multirow{2}{*}{ Light trucks } & Petrol & 100.0 & 80.0 & 300 & 14.0 & 40 & 0.02 & 0.045 \\
\hline & Diesel & 80.0 & 8.0 & 15 & 13.0 & 18 & 2.00 & 4.000 \\
\hline \multirow{2}{*}{ Heavy trucks } & Diesel & 240.0 & 6.5 & 10 & 30.0 & 45 & 0.70 & 2.000 \\
\hline & $\mathrm{CNG}$ & 500.0 & 2.2 & 15 & 5.5 & 30 & 0.01 & 0.036 \\
\hline Motorcycles & Petrol & 35.0 & 340.0 & 700 & 1.1 & 8 & 1.50 & 5.000 \\
\hline Public buses & $\mathrm{CNG}$ & 500.0 & 2.2 & 15 & 5.5 & 30 & 0.01 & 0.036 \\
\hline
\end{tabular}

A regression of the type:

$\mathrm{P}(\mathrm{X})_{\mathrm{t}}=\mathrm{C}+\alpha_{1} \mathrm{P}(\mathrm{X}) \mathrm{A}_{\mathrm{t}}+\alpha_{2} \mathrm{P}(\mathrm{X}) \mathrm{L}_{\mathrm{t}}+\alpha_{3} \mathrm{P}(\mathrm{X}) \mathrm{M}_{\mathrm{t}}+\alpha_{4} \mathrm{P}(\mathrm{X}) \mathrm{P}_{\mathrm{t}}+\alpha_{5} \mathrm{P}(\mathrm{X}) \mathrm{T}_{\mathrm{t}}+$ ut, was estimated to find out the impact of pollutant emission of vehicles on total air pollution measured by concentration of pollutants (hourly averages in $\mu \mathrm{g} / \mathrm{m}^{3}$ ). The explained variable was $\mathrm{P}(\mathrm{X})$, which denotes the amount of the pollutant, $X=C O, N O x, P M 2.5$, respectively. Explanatory variables were emission levels $(\mathrm{g} / \mathrm{km})$ of vehicles, $\mathrm{P}(\mathrm{X}) \mathrm{P}$ for private cars, $\mathrm{P}(\mathrm{X}) \mathrm{L}$ for light trucks, $\mathrm{P}(\mathrm{X}) \mathrm{T}$ for heavy trucks, $\mathrm{P}(\mathrm{X}) \mathrm{M}$ for motorcycles, and $\mathrm{P}(\mathrm{X}) \mathrm{A}$ for public buses. Here, $\mathrm{u}_{\mathrm{t}}$ denotes the error term and $\mathrm{t}$ is the time index.

The biggest pollutants with carbon monoxide are light trucks running on petrol, and a decrease in emission by $1 \mathrm{~g} / \mathrm{km}$ could decrease the CO level by $2.4 \mu \mathrm{g} / \mathrm{m}^{3}$. Also, motorcycles could decrease the $\mathrm{CO}$ 
level in air by $1.6 \mu \mathrm{g} / \mathrm{m}^{3}$. Diesel trucks have significantly lower $\mathrm{CO}$ emission. The motorcycle engine construction is the biggest issue, enabling high levels of gas emissions. Nitrogen oxides emission is dominated by private cars, since the related coefficient is the highest. The private cars running on petroleum gas produce the highest levels of NOx. Due to the current price of gas it is unlikely to see a decrease in NOx emissions. The highest emission of particulate matter comes from motorcycles, and a decrease in emission by $1 \mathrm{~g} / \mathrm{km}$ could decrease the levels of PM2.5 by $2.8 \mu \mathrm{g} / \mathrm{m}^{3}$ (Table 8 ).

Table 8. Coefficient estimates.

\begin{tabular}{|c|c|c|c|c|c|c|c|c|c|c|c|}
\hline \multicolumn{4}{|c|}{ Dependent Variable: $\mathrm{P}(\mathrm{CO})$} & \multicolumn{4}{|c|}{ Dependent Variable: P(NOx) } & \multicolumn{4}{|c|}{ Dependent Variable: P(PM2.5) } \\
\hline Var & B & $\mathbf{t}$ & $p$ & Var & B & $\mathbf{t}$ & $p$ & Var & B & $\mathbf{t}$ & $p$ \\
\hline $\mathrm{P}(\mathrm{CO}) \mathrm{P}$ & 0.560 & 2.947 & 0.032 & $\mathrm{P}(\mathrm{NOx}) \mathrm{P}$ & 0.812 & 5.376 & 0.003 & $\mathrm{P}(\mathrm{PM} 2.5) \mathrm{P}$ & 0.838 & 2.332 & 0.067 \\
\hline $\mathrm{P}(\mathrm{CO}) \mathrm{L}$ & 2.390 & 5.893 & 0.002 & $\mathrm{P}(\mathrm{NOx}) \mathrm{L}$ & 0.568 & 4.570 & 0.006 & $\mathrm{P}(\mathrm{PM} 2.5) \mathrm{L}$ & 1.158 & 5.829 & 0.002 \\
\hline $\mathrm{P}(\mathrm{CO}) \mathrm{T}$ & 0.024 & 4.773 & 0.005 & $\mathrm{P}(\mathrm{NOx}) \mathrm{T}$ & 0.245 & 5.224 & 0.003 & $\mathrm{P}(\mathrm{PM} 2.5) \mathrm{T}$ & 1.075 & 4.570 & 0.006 \\
\hline $\mathrm{P}(\mathrm{CO}) \mathrm{M}$ & 1.600 & 8.363 & 0.000 & $\mathrm{P}(\mathrm{NOx}) \mathrm{M}$ & 0.047 & 3.095 & 0.027 & $\mathrm{P}(\mathrm{PM} 2.5) \mathrm{M}$ & 2.812 & 2.800 & 0.038 \\
\hline $\mathrm{P}(\mathrm{CO}) \mathrm{A}$ & 0.390 & 2.715 & 0.021 & $\mathrm{P}(\mathrm{NOx}) \mathrm{A}$ & 0.125 & 3.516 & 0.017 & P(PM2.5)A & 0.117 & 4.403 & 0.007 \\
\hline 0.956 & Mean c & ep.var & 66.13 & 0.949 & Meand & p. var & 76.32 & 0.907 & Meand & ep.var & 41.94 \\
\hline
\end{tabular}

This study only covered motorcycles running on gas, while for other types of vehicles the range of consumptions and types of fuels were used in order to obtain weighted consumption. We assumed that truck usage cannot be replaced by PT; hence results for both types of trucks are for control purpose only. However, decreasing the number of motorcycles in favor of PT would have a beneficial effect in terms of decreasing both $\mathrm{CO}$ and PM levels.

In line with Example 1, if we remove motorcycles and replace them with bicycles, reduction in emissions for 70 motorcycles, per $1 \mathrm{~km}$ is:

\begin{tabular}{|l|r|r|r|r|}
\hline & mot & mot & tot mot & tot mot \\
\hline CO & 11.9 & 24.5 & 833 & 1715 \\
\hline NO & 0.0385 & 0.28 & 2.695 & 19.6 \\
\hline PM & 0.0525 & 0.175 & 3.675 & 12.25 \\
\hline
\end{tabular}

Respondents for the questionnaire were acquainted with the upper results. It was specially pointed out that public buses do contribute to air pollution, but mainly at lower levels than other transportation means. Of special interest is then to compare private cars and public buses: public buses have advantages in CO emission, in NOx emission, and in PM2.5 emission as well. Having this information, the respondents were asked if they think that it is convenient to introduce hybrid buses for city PT to reduce air pollution (Q14). The answers were positive in general, on the scale from 1 to 10 the average answer was $4.48( \pm 0.85)$. This means that young people are convinced that any, even minimal improvement in environment protection is useful and necessary. The next question in the questionnaire was different from previous ones, namely the respondents were asked about the popularization of bicycles, that will cause their use to be more frequent, and that will contribute to air pollution reduction $(\mathrm{Q} 15)$. All agree that this would be a proper action, and they gave an average score of $4.41( \pm 0.96)$. This seems to be very convenient, when thinking about problems in general. Contrary to that, when respondents were asked about their willingness to use mainly bicycles for city mobility in the case that all the necessary bicycle paths are constructed in their town (Q16) (the respondents were informed about the next: City of Subotica is relatively well covered with bicycle roads and paths. In 2019 , the total length was $41 \mathrm{~km}$, i.e., $0.14 \mathrm{~km} / \mathrm{km}^{2}$ of area) as in Figure 3, the average score was pretty low and amounted to $3.52( \pm 1.31)$. This average score is highly significantly smaller than the score for question $\mathrm{Q} 15(\mathrm{t}=7.769, p=0.0000)$; besides that, here the variations are relatively great (variation coefficient $\mathrm{V}=37.24 \%$ ), meaning there is a great level of disagreement about using bicycles among these young respondents. When looking for connectedness of willingness to use bicycles with answers 
to any of the first 13 questions (satisfaction with city PT), it appears that there are two significant correlations, namely with the level of satisfaction with Q2: travel time $(r=0.145, p=0.020)$ and Q3: punctuality of buses $(r=0.129, p=0.034)$. As expected, agreement between answers for question Q15: popularization of bicycles contributes to air pollution reduction and Q16: willingness to use bicycles was significant $(\mathrm{r}=0.379, p=0.000)$. One may conclude that the awareness of young people about common problems leads to undertaking proper actions useful for the whole of society.

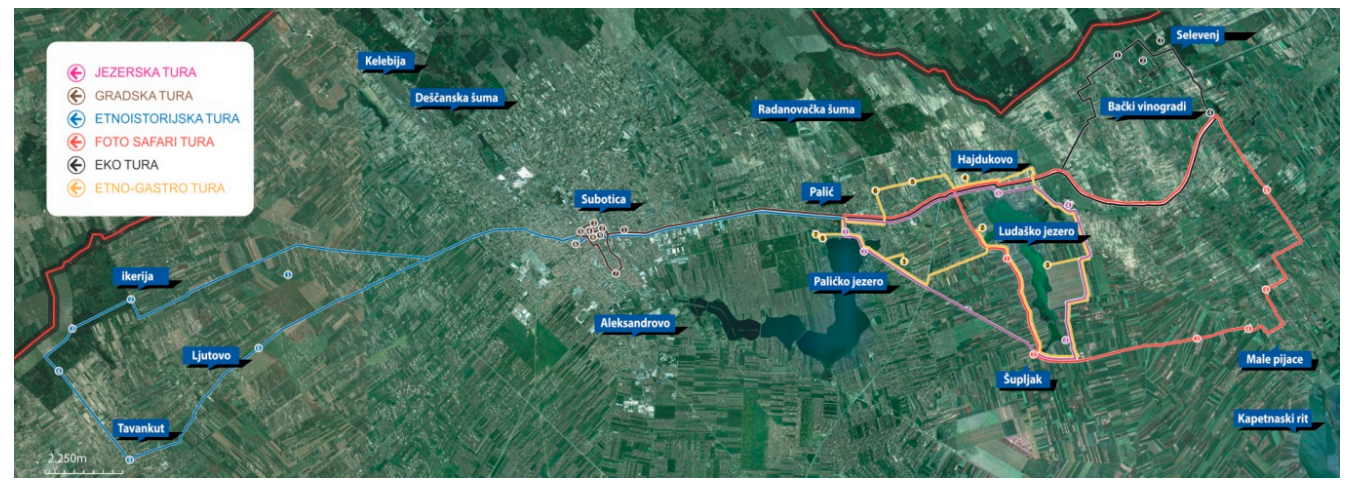

Figure 3. Cycling tours in Subotica (Source: Park Palic "Palic Cikloturizam").

\section{Conclusions}

The paper focused on determinants of the three dimensions of sustainable PT in the city of Subotica, Serbia. We were interested on the viewpoint of younger generations, aged 18-26. Economic and social dimensions were measured using questionnaire defining the set of variables that the youngest PT users find the most important.

We applied factor analysis and detected four factors embedding the 13 original variables that affected the overall score. The original variables were factored in the following way: general travel information, general on-board comfort, general bus stop condition and punctuality/price.

The four-factor split is in line with Fellesson and Friman [27], with general comfort being cognitively separated from the other aspects. The same holds for bus stop conditions. On the other hand, the issue of general security is not encompassed by a single factor but is loaded in other factors. We can argue that young PT users are not occupied with security issues.

One of the important managerial implications of this paper is that practitioners need to thoroughly reconsider how they measure and interpret satisfaction data. The current study highlights the important role of comfort for young traveler satisfaction. For future research we have to link the generational theory with the satisfaction of public transportation and to compare the results between generations. For further research we shall expand the current set of explanatory variables and apply the structural equation model in order to allow mutual dependencies between variables.

The results of the ecological dimension of sustainable transport were obtained from series of regression, which show that almost all of the air pollutants in the city center can be explained by traffic emissions. Hence, technological modernization and renewable energy access as well as investments in environmentally friendly projects should gain momentum in the years to come in order to decrease the emission of potentially harming substances. Therefore, there is a great opportunity for creating green jobs in Serbia, but only with sustainable and massive investments in the public and private sectors. The government and all the stakeholders have to create a framework for the adoption of green economy $[43,44]$.

According to the general sustainability plan for the city of Subotica, for the period 2013-2022, Subotica has good potential in further expanding bicycle traffic. It is estimated that $20 \%$ of all individual traffic in the city will be conveyed by bicycle by the year 2022. The plan predicts the construction of bicycle lanes throughout the city. We calculated the emission reduction if motorcycles were replaced with bicycles. 
Author Contributions: Conceptualization, D.S. and O.S.; Data curation, D.S.; Formal analysis, A.M.H.; Investigation, D.S., A.M.H.; Methodology, Z.C. and O.S.; Resources, Z.C. and A.M.H.; Software, D.S.; Validation, O.S.; Writing-original draft, D.S., Z.C., O.S. and A.M.H.; Writing—review \& editing, Z.C. and O.S. All authors have read and agreed to the published version of the manuscript.

Funding: This research received no external funding.

Conflicts of Interest: The authors declare no conflict of interest.

\section{References}

1. Anable, J. 'Complacent car addicts' or 'aspiring environmentalist'? Identifying travel behaviour segments using attitude theory. Transp. Policy 2005, 12, 65-78. [CrossRef]

2. Replogle, M.E.; Fulton, L. A Global High Shift Scenario. Impacts and Potential for More PT. Walking and Cycling with Lower Car Use; Institue for Transportation and Development Policy (ITDP): New York, NY, USA, 2014.

3. Currie, G.; Wallis, I. Effective ways to grow urban bus markets-a synthesis of evidence. J. Transp. Geogr. 2018, 16, 419-429. [CrossRef]

4. Blaž, J.; Zajc, K.; Zupan, S.; Ambrož, M. Evaluation System for the Implementation of Public Passenger Transport as a Public Service Obligation. Sustainability 2019, 11, 3294. [CrossRef]

5. Mouwen, A. Drivers of customer satisfaction with PT services. Transp. Res. Part A Policy Pract. 2015, 78, 1-20. [CrossRef]

6. Oliver, R.L. A cognitive model of the antecedents and consequences of satisfaction decisions. J. Mark. Res. 1980, 17, 460-469. [CrossRef]

7. Zeithaml, A.; Parasuraman, A.; Berry, L. Delivering Quality Service; The Free Press: New York, NY, USA, 1990.

8. Grigoroudis, E.; Siskos, Y. Preference disaggregation for measuring and analyzing customer satisfaction: The MUSA method. Eur. J. Oper. Res. 2002, 143, 148-170. [CrossRef]

9. Vujić, M.; Mandžuka, S.; Gregurić, M. Pilot implementation of PT priority in the City of Zagreb. Promet Traffic Transp. 2015, 27, 257-265.

10. Yi, Y.; Ma, S.; Guan, W.; Li, K. An Empirical Study on the Relationship between Urban Spatial Form and CO2 in Chinese Cities. Sustainability 2017, 9, 672. [CrossRef]

11. Andreassen, T.W. (Dis)satisfaction with public services: The case of PTation. J. Prof. Serv. Mark. 1995, 9, 30-41. [CrossRef]

12. Baltes, M.R. The importance customers place on specific service elements of bus rapid transit. J. Ptation 2003, 6, 1-19. [CrossRef]

13. Eboli, L.; Mazzulla, G. A new customer satisfaction index for evaluating transit services quality. J. Ptation 2009, 12, 21-38. [CrossRef]

14. Tyrinopoulos, Y.; Antoniou, C. PT user satisfaction: Variability and policy implications. Transp. Policy 2008, 15, 260-272. [CrossRef]

15. Zhang, C.; Wang, D.; Ni, A.; Ni, X.; Xiao, G. Different Effects of Contractual Form on PT Satisfaction: Evidence from Large- and Medium-Sized Cities in China. Sustainability 2019, 11, 5453. [CrossRef]

16. Dell'Olio, L.; Ibeas, A.; Cecin, P. The quality of service desired by PT users. Transp. Policy 2011, 18, $217-227$. [CrossRef]

17. Diana, M. Measuring the satisfaction of multimodal travelers for local transit services in different urban contexts. Transp. Res. Part A Policy Pract. 2012, 46, 1-11. [CrossRef]

18. Brons, M.; Rietveld, P. Improving the quality of the door-to-door rail journey: A customer-oriented approach. Built Environ. 2009, 35, 30-43. [CrossRef]

19. Ivanovic-Đukić, M.; Đorđević, B.; Lepojević, V. Mediating Effects of Educational Level on Job Related Characteristics-Job Satisfaction Relationship. Strateg. Manag. (Int. J. Strateg. Manag. Decis. Support Syst. Strateg. Manag.) 2018, 23, 13-21. [CrossRef]

20. Cronin, J.J. Looking back to see forward in service marketing: Some ideas to consider. Manag. Serv. Qual. 2003, 13, 332-337. [CrossRef]

21. Brezina, T.; Schopf, J.M.; Badillo, D.M. Public transit service-opportunities in commuter-belt municipalities-A systemic analysis of two districts in the Vienna region. Promet Traffic Transp. 2015, 27, 247-255. [CrossRef]

22. Ševrović, M.; Brčić, D.; Kos, G. Transportation costs and subsidy distribution model for urban and suburban public passenger transport. Promet Traffic Transp. 2015, 27, 23-33. [CrossRef] 
23. Moslem, S.; Ghorbanzadeh, O.; Blaschke, T.; Duleba, S. Analysing Stakeholder Consensus for a Sustainable Transport Development Decision by the Fuzzy AHP and Interval AHP. Sustainability 2019, 11, 3271. [CrossRef]

24. Ellaway, A.; Macintyre, S.; Hiscocl, R.; Kearns, A. In the driving seat: Psychosicial benefits from private motor vehicle transport compared to PT. Transp. Res. Part F Traffic Psy. Behav. 2003, 6, 217-231. [CrossRef]

25. Available online: http://www.gov.uk/government/organisations/department-for-transport (accessed on 1 August 2020).

26. Cordera, R.; Nogues, S.; Gonzales-Gonzales, E.; del Ollio, L. Intra-Urban Spatial Disparities in User Satisfaction with Public Transport Services. Sustainability 2019, 11, 5829. [CrossRef]

27. Gatersleben, B.; Uzzel, D. Affective Appraisals of the daily commute: Comparing perception of the drivers, cyclist, walkers, and users of PT. Environ. Behav. 2007, 39, 416-431. [CrossRef]

28. Fellesson, M.F.; Friman, M. Perceived satisfaction with PT service in nine European cities. J. Transp. Res. Forum 2008, 47, 93-103.

29. Eboli, L.; Mazzulla, G. Service quality attributes affecting customer satisfaction for bus transit. J. Public Transp . 2007, 10, 21-34. [CrossRef]

30. Rana, I. Measuring Public Transport Satisfaction from User Surveys. Int. J. Bus. Manag. 2014, 9, 106-114. [CrossRef]

31. De Oña, J.; de Oña, R. Quality of Service in Public Transport Based on Customer Satisfaction Surveys: A review and assessment of methodological approaches. Transp. Sci. 2015, 49, 605-622. [CrossRef]

32. Allen, J.; Muñoz, J.C.; de Dios Ortúzar, J. Modelling service-specific and global transit satisfaction under travel and user heterogeneity. Transp. Res. Part A Policy Pract. 2018, 113, 509-528. [CrossRef]

33. Shen, W.; Xiao, W.; Wang, X. Passenger satisfaction evaluation model for Urban rail transit: A structural equation modeling based on partial least squares. Transp. Policy 2016, 46, 20-31. [CrossRef]

34. Kral, P.; Janoskova, K.; Kliestik, K. Key determinants of the public transport user's satisfaction. Adm. Manag. Public 2018, 31, 36-51. [CrossRef]

35. May, D. Urban Transport and Sustainability: The Key Challenges. (Issue 3: Modeling for Sustainable Urban Transportation). Int. J. Sustain. Transp. 2013, 7, 170-185. [CrossRef]

36. Alonso, A.; Monzon, A.; Cascajo, R. Comparative analysis of passenger transport sustainability in European cities. Ecol. Indic. 2015, 48, 578-592. [CrossRef]

37. Miletić, G.M.; Gašparović, S.; Carić, T. Analysis of socio-spatial differentiation in transport mode choice preferences. Promet Traffic Transp. 2017, 29, 233-242. [CrossRef]

38. Stuart, K.R.; Mednick, M.; Bockman, J. Structural Equation Model of Customer Satisfaction for the New York City Subway System. Transp. Res. Rec. J. Transp. Res. Board 2000, 1735, 133-137. [CrossRef]

39. BEST Organizing Committee. BEST Results of the 2006 Survey; BEST Organizing Committee: Oslo, Norway, 2006.

40. Kaiser, H.F. The application of electronic computers to factor analysis. Educ. Psychol. Meas. 1960, 20, 101-119. [CrossRef]

41. Papic, V.; Vidovic, M.; Manojlovic, A.; Momcilovic, V.; Trifunovic, J.; Vukadinovic, K.; Popovic, J.; Miljus, M.; Medar, O.; Bijelic, N.; et al. Odredjivanje Kolicina Emitovanih Gasovitih Zagadjujucih Materija Poreklom Od Drumskog Saobracaja Primenom COPERT IV Modela Evropske Agencije za Zivotnu Sredinu; Institut Saobracajnog Fakulteta, University of Belgrade: Belgrade, Serbia, 2010.

42. Koliko se Vozila Kreće Putevima Srbije i Koliko ih je Više u 2018? Available online: https://www.b92.net/ automobili/aktuelno.php?yyyy=2019\&mm=01\&nav_id=1490807 (accessed on 1 August 2020).

43. Vukadinovic, S.; Jesic, J. Green jobs: Potential for employment in the Republic of Serbia. Ann. Fac. Econ. Subot. 2019, 55, 115-129. [CrossRef]

44. Milovanov, O. Marketing and Sustainability: Identifying the Profile of Green Consumers. Strateg. Manag. (Int. J. Strateg. Manag. Decis. Support Syst. Strateg. Manag.) 2015, 20, 54-66.

Publisher's Note: MDPI stays neutral with regard to jurisdictional claims in published maps and institutional affiliations. 